\title{
Tomasz KOŚMIDER
}

Akademia Sztuki Wojennej w Warszawie

t.kosmider@akademia.mil.pl

\section{Robert Łoś, Soft power we wspótczesnych stosunkach miedzynarodowych}

\author{
Wydawnictwo Uniwersytetu Łódzkiego, Łódź 2017, 323 s.
}

Określenie istoty, cech, funkcji oraz poziomu bezpieczeństwa podlega ewolucji w zależności od zmieniających się czynników politycznych, gospodarczych, społecznych czy kulturalnych. Współczesny system bezpieczeństwa musi sprostać różnym wyzwaniom i zagrożeniom, być gotowy do wykorzystania pojawiających się szans, a także reagować na sytuacje niebezpieczne, w tym sytuacje kryzysowe (militarne i niemilitarne). Mapa zagrożeń współczesnego świata charakteryzuje się dużą różnorodnością, obejmując m.in.: terroryzm (cyberterroryzm), proliferację broni masowego rażenia, zagrożenia asymetryczne, hybrydowe, konflikty regionalne, procesy migracyjne, nacjonalizmy, przestępczość zorganizowaną, niewydolność państw, a także różnego rodzaju kataklizmy i zdarzenia o znamionach klęsk żywiołowych oraz inne, mające wpływ na bezpieczeństwo ludności i system obronny państwa. Warto wspomnieć też o zagrożeniach ekonomicznych, stanowiących pokłosie rozdźwięku między anarchiczną strukturą systemu bezpieczeństwa międzynarodowego a ekonomiczną strukturą rynku. Wszystko to narzuca konieczność podejmowania wielopłaszczyznowych działań uwzględniających problematykę bezpieczeństwa. Zachodząca jakościowa zmiana środowiska bezpieczeństwa powoduje, że do jego opisu nie wystarczają już klasyczne kategorie wojny i pokoju.

Współczesne środowisko bezpieczeństwa, w którym wzrasta znaczenie aktorów niepaństwowych (korporacje ponadnarodowe, grupy ekstremistyczne, organizacje pozarządowe, ruchy społeczne itp.), charakteryzuje zacieranie granic między jego wymiarem wewnętrznym i zewnętrznym, militarnym i pozamilitarnym. Jest to jakościowo nowa sytuacja, która wymaga zmiany w podejściu państwa do spraw bezpieczeństwa, które przestało być ograniczane tylko do wymiaru militarnego, rozszerzając się o inne 
kategorie, np. energetyczne czy kulturowe ${ }^{1}$. Oprócz środków militarnych i ekonomicznych w działaniach kształtujących środowisko bezpieczeństwa coraz większe znaczenie zyskują inne czynniki. Cele strategiczne realizowane są także poprzez wykorzystanie atrakcyjności kultury, systemu wartości czy stylu polityki pozbawionej agresji, co często określane jest mianem soft power.

Soft power - spopularyzowana przez Josepha Nye’a - jest pojęciem dość trudnym do zdefiniowania. Równie dobrze - jak podkreśla autor książki - może oznaczać miękka wtadzę bądź sitę, trzecie oblicze wtadzy bądź sity. Najlepiej soft power określić jako miękka site, ponieważ uniknie się niekonsekwencji terminologicznych, gdy konsekwentnie hard power określimy jako twarda sitę ${ }^{2}$. Poważny problem stanowi przede wszystkim brak możliwości przeprowadzenia pełnej i klarownej oceny oraz podziału na sfery hard i soft power. Nie ulega wątpliwości, że decyduje o tym zarówno rodzaj zasobów, mechanizm działania, jak i zakres kontroli ze strony podmiotów prawa międzynarodowego. Poza tym soft power, której genezy możemy doszukiwać się w starochińskiej myśli wojskowej, nie należy sprowadzać wyłącznie do zasobów pozamilitarnych i pozaekonomicznych, gdyż byłoby to nieuzasadnionym uproszczeniem.

Soft power nie sposób poddać pełnej kontroli. Stanowi to poważny problem dla państwa, dysponującego instrumentami pozwalającymi zdecydowanie bardziej nadzorować zasoby wojskowe i ekonomiczne. Co ciekawe, w odniesieniu do narodu (wspólnoty) jest zupełnie na odwrót. Nie oznacza to jednak, że państwo nie może wykorzystywać zasobów soft power.

Nie mniej istotne pozostaje ustalenie, na ile ten nowy rodzaj sily jest w stanie budować i stabilizować światowy porządek i czy ma to wymiar działań doraźnych, czy też charakter ewolucyjny, wykazując skuteczność w rozwiązywaniu problemów globalnych. Istotna pozostaje symetria poszczególnych kategorii soft power, pozwalająca w sposób optymalny wykorzystać miękki potencjał zasobów. Oddziaływanie to, którego nie należy przeceniać, może mieć wymiar aktywny, w którym przeważają instrumenty politycznego reagowania (w znacznym stopniu przesądzające o klasyfikacji siły) lub pasywny z dominacją zasobów (wartości, kultura, polityka zagraniczna, dyplomacja publiczna - obejmująca aspekty stosunków międzynarodowych, wykraczające poza tradycyjną dyplomację, dyplomacja kulturalna i branding narodowy, związany z budowaniem wizerunku państwa oraz media). Nie należy jednak zapominać, że skuteczne oddziaływanie soft power wymaga wsparcia hard power w postaci siły militarnej czy ekonomicznej. Jest to też jeden ze sposobów budowania przestrzeni pozwalającej na wykorzystanie miękkich narzędzi wpływu. Relacje zachodzące między twardą a miękką siłą zostały przedstawione dość obrazowo przez Nialla Fergusona, zdaniem którego soft power można potraktować jako delikatna rękawiczkę leżaca na żelaznej ręce ${ }^{3}$.

1 Ł. Fijałkowski, Teoria sekurytyzacji i konstruowanie bezpieczeństwa, „Przegląd Strategiczny” 2012, nr 1, s. $150-187$.

2 R. Łoś, Soft power we wspótczesnych stosunkach międzynarodowych, Łódź 2017, s. 11.

3 N. Ferguson, Colossus. The Price of America’s Empire, New York 2004, s. 24. 
Problematyka ta stanowi treść książki profesora Uniwersytetu Łódzkiego Roberta Łosia, zatytułowanej Soft power we wspótczesnych stosunkach międzynarodowych. Jej konstrukcja, jak autor zaznaczył we wstępie, została zdeterminowana trudnościami w uchwyceniu zakresu soft power i miejsca tego rodzaju sity w ogólnej sile państwa. Praca składa się ze wstępu, czterech rozdziałów, zakończenia oraz bibliografii. Uzupełniają ją tabele, wykresy oraz schematy pozwalające lepiej udokumentować treści zawarte w poszczególnych rozdziałach. Struktura pracy nie budzi zastrzeżeń, choć złożoność tematu sprawia, że autor w kwestiach szczegółowych musiał w kilku przypadkach szukać kompromisu pomiędzy przyjętymi założeniami a potrzebami realizacji niektórych problemów szczegółowych.

Rozdział pierwszy, zatytułowany Potega i tad międzynarodowy, stanowiąc swego rodzaju introdukcję, tworzy dobrą podstawę merytoryczną do realizacji kolejnych rozdziałów. Autor po zaprezentowaniu głównych nurtów stosunków międzynarodowych skoncentrował się na analizie procesów, do których doszło na przełomie XX i XXI stulecia $\mathrm{w}$ światowym porządku, które wymusiły zredefiniowanie miejsca i roli soft power $\mathrm{w}$ realizacji celów polityczno-strategicznych w wymiarze globalnym, regionalnym i krajowym. Stosowanie soft power nie jest równoznaczne z wyrzeczeniem się stosowania siły w przestrzeni publicznej.

Zasoby $i$ instrumenty miękkiej sity - to tytuł kolejnego rozdziału, w którym zostały przedstawione nie tylko zasoby soft power, ale także relacje zachodzące z hard power wraz z narzędziami oddziaływania. Wiele miejsca zajmuje też kwestia oddziaływania na soft power mechanizmów ustrojowych związanych z instytucjami państwa oraz trudniejszych do określenia - społecznych uwarunkowań, budowanych w wyniku skomplikowanych procesów oddolnych, samoidentyfikacji itp.

Normy i wartości należy postrzegać jako integralny składnik przejawiania się siły w stosunkach międzynarodowych, nie tylko w wymiarze legitymizacji podejmowanych tzw. miękkich działań, ale także istotny czynnik spajający wysiłki podejmowane na rzecz budowania zdolności obronnej państwa, tworząc takie społeczne emocje, jak poczucie tożsamości wspólnoty czy inspirowanie do aktywności na rzecz ustalonego celu politycznego ${ }^{4}$. Problemem pozostaje sposób, w jaki wartości są wykorzystywane w sferze polityki i bezpieczeństwa, aby mogły stanowić źródło przyciągania, aprobaty czy celowej zmiany trwałych postaw.

Praktyczne zaprezentowanie potencjału soft power, poprzez odniesienie go do wymiernych wskaźników określających skalę uzyskiwanej potęgi, znajduje się w rozdziale trzecim. W pierwszej kolejności analizie poddano kryteria niezbędne do określenia siły państwa, przebadano więc potencjał demograficzny i terytorialny, siły zbrojne oraz ekonomię. Stanowi to wprowadzenie do dalszych badań, w których ważne miejsce zajmuje dyplomacja, zasób społeczno-polityczny, kultura popularna i wysoka, nauka i edukacja (wraz z think tankami) oraz kategoria społeczno-gospodarcza. Zasadnicze kategorie i określone czynniki wpływu zostały usystematyzowane proporcjonalnie do

N. Stammers, A Critique of Social Approaches to Human Rights, „Human Rights Quarterly” 1995, nr 17, s. 488 . 
ich znaczenia. Przedstawiony, autorski ranking określający miękką siłę wpływu państwa - obejmuje 30 państw i określa liderów w kategorii soft power - stanowi interesującą propozycję badawczą, tym bardziej, że obecne źródła siły wpływu są dość rozproszone, a ponadto ulegają modyfikacji w czasie, co znacznie utrudnia jej mierzenie.

Koncentrowanie się na twardej sile, a niedocenianie soft power może niekorzystnie wpłynąć na efekt realizowanych projektów, czego ilustracją może być chociażby prowadzona II wojna w Zatoce Perskiej (dodajmy, że zupełnie inaczej kwestia ta przedstawiała się w roku 1990). Stosowanie soft power, która nie może być postrzegana jako alternatywa dla hard power, wymaga dość skomplikowanej analizy skuteczności jej użycia, prowokując do stosowania rozwiązań skuteczniejszych, a mianowicie twardej siły. Należy mieć także na uwadze, co akcentuje część analityków, że soft power trudno odnosić do polityki rządu, ponieważ jego źródła tkwią w społeczeństwie. Ciekawe wnioski płyną z analizy podejmowanych działań w tym zakresie na gruncie amerykańskim, chińskim i rosyjskim. Tematyka ta stanowi treść rozdziału czwartego.

Soft power wraz z czynnikami twardymi stanowi o pozycji i sile państwa. Synteza czynników miękkich i twardych, na co zwraca uwagę Robert Łoś, jest dowodem na inteligentne podejście do zrównoważenia polityki zagranicznej oraz umiejętnego korzystania $z$ zasobów $w^{5}$. Wymaga to połączenia obydwu aspektów siły tak, aby ich wzajemne uzupełnianie się prowadziło do efektywnej realizacji przyjętych celów. Chodzi przy tym nie tylko o reakcję na zagrożenia i ich skutki, ale wykorzystanie w realizacji polityki bezpieczeństwa wszelkich dostępnych środków stwarzających warunki, w których pojawienie się zagrożeń i ich skutków byłoby mało prawdopodobne lub mniej dotkliwe dla państwa i społeczeństwa.

Monografia, odznaczając się ciekawym spojrzeniem na poruszaną problematykę, w znaczący sposób wypełnia lukę, która istnieje w polskiej historiografii w obszarze stosunków międzynarodowych, stanowiąc punkt wyjścia dla wszystkich zainteresowanych kwestiami zagrożeń militarnych i pozamilitarnych występujących we współczesnym świecie. Należy podkreślić, że książka otrzymała solidną formę edytorską, co jest zasługą zarówno redaktorów, jak i wydawnictwa. Monografia jest dojrzałą próbą odpowiedzi na zawarte w niej pytania badawcze, a prezentowane w niej zagadnienia należą do interesujących. Niewątpliwie warta jest lektury i zasługuje, aby polecić ją czytelnikom, których może zaskoczyć nie tylko wielość powiązań łączących analizowane kategorie, ale także liczne akcenty nowatorskie.

\footnotetext{
R. Łoś, Soft power..., s. 291.
} 